\title{
Stereocontrolled Total Synthesis of Potent Immunosuppressant FR901483
}

Toshiyuki Kan, Teppei Fujimoto, Shigeru Ieda, Yusuke Asoh, Haruka Kitaoka and Tohru Fukuyama*

\section{Supporting Information}

3-[2-(2-Methoxycarbonyl-ethyl)-5-oxo-pyrrolidin-2-yl]-propionic acid methyl ester (5).
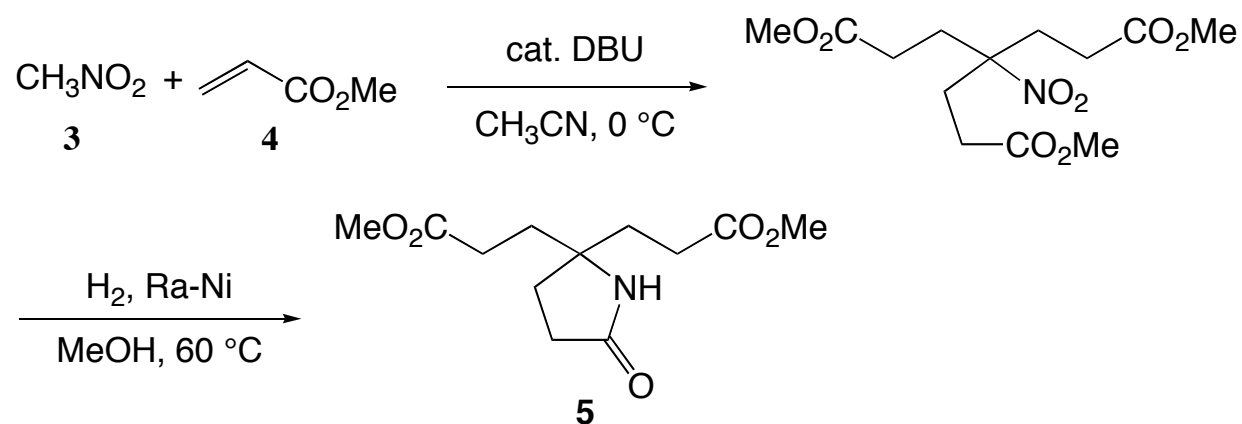

To a stirred solution of $\mathrm{CH}_{3} \mathrm{NO}_{2}(20.0 \mathrm{~g}, 328 \mathrm{mmol})$ in $\mathrm{CH}_{3} \mathrm{CN}(400 \mathrm{ml})$ at $0{ }^{\circ} \mathrm{C}$ were added methyl acrylate $(118 \mathrm{ml}, 1.32 \mathrm{~mol})$ and DBU $(5.40 \mathrm{ml}, 36.2 \mathrm{mmol})$. After stirring at $0{ }^{\circ} \mathrm{C}$ for $30 \mathrm{~min}$, saturated aqueous ammonium chloride was added and the mixture was extracted with $\mathrm{Et}_{2} \mathrm{O}$. The combined organic layer was washed with brine then dried over $\mathrm{MgSO}_{4}$. The solvent was removed under reduced pressure and the resulting oil (107 $\mathrm{g})$ was used in the next reaction without further purification: ${ }^{1} \mathrm{H}-\mathrm{NMR}\left(\mathrm{CDCl}_{3}, 400 \mathrm{MHz}\right) \square 2.24-2.35(12 \mathrm{H}, \mathrm{m}), 3.70(9 \mathrm{H}, \mathrm{s}) ;{ }^{13} \mathrm{C}-\mathrm{NMR}\left(\mathrm{CDCl}_{3}\right.$, $100 \mathrm{MHz}) \square 28.4,30.2,52.0,91.8,172.1$; IR (film) 1738, 1538, 1438, $1176 \mathrm{~cm}^{-1}$.

To a stirred solution of foregoing crude product $(50.0 \mathrm{~g})$ in $\mathrm{MeOH}(250 \mathrm{ml})$ at room temperature was added $\mathrm{Ra}-\mathrm{Ni}\left(\mathrm{W}_{2}\right)(5.00 \mathrm{~g})$. After stirring at $60{ }^{\circ} \mathrm{C}$ under hydrogen gas atmosphere $\left(5 \mathrm{kgw} / \mathrm{cm}^{2}\right)$ for 6 hours, the mixture was filtered through a pad of Celite and washed with methanol. The solvent was removed under reduced pressure and the resulting crude product of 5 (40.8 $\mathrm{g})$ was used in the next reaction without further purification: ${ }^{1} \mathrm{H}-\mathrm{NMR}\left(\mathrm{CDCl}_{3}, 400 \mathrm{MHz}\right) \square 1.82-1.96(6 \mathrm{H}, \mathrm{m}), 2.30$ $2.47(6 \mathrm{H}, \mathrm{m}), 3.69(6 \mathrm{H}, \mathrm{s}), 6.85(1 \mathrm{H}, \mathrm{s}) ;{ }^{13} \mathrm{C}-\mathrm{NMR}\left(\mathrm{CDCl}_{3}, 100 \mathrm{MHz}\right) \square 28.7,30.2,34.6,51.9,60.6$, 173.5, 177.3; IR (film) 3213, 3086, 2953, 1731, 1696, $1436 \mathrm{~cm}^{-1}$; HRMS (FAB) calcd for $\mathrm{C}_{12} \mathrm{H}_{20} \mathrm{NO}_{5} 258.1336\left[(\mathrm{M}+\mathrm{H})^{+}\right]$, found 258.1326. 

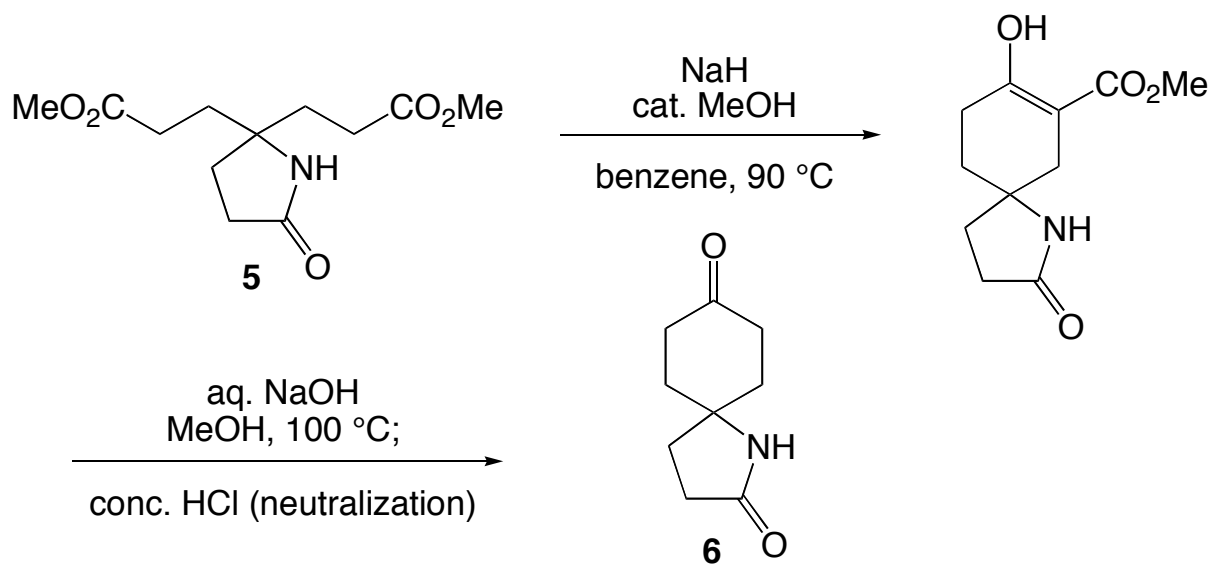

To a stirred solution of foregoing crude product of $5(20.0 \mathrm{~g})$ in benzene $(150 \mathrm{ml})$ at $0{ }^{\circ} \mathrm{C}$ was added $\mathrm{MeOH}$ (315 $\square \mathrm{l}, 7.77 \mathrm{mmol}$ ) followed by $\mathrm{NaH}(7.77 \mathrm{~g}, 194 \mathrm{mmol})$. After stirring at $90{ }^{\circ} \mathrm{C}$ for $30 \mathrm{~min}$, aqueous $3 \mathrm{~N} \mathrm{HCl}$ was added and the mixture was extracted with AcOEt. The combined organic layer was washed with saturated aqueous sodium bicarbonate and brine then dried over $\mathrm{MgSO}_{4}$. The solvent was removed under reduced pressure. Resulting solid residue was triturated with hexane to afford the keto-ester $\left(12.8 \mathrm{~g}, 56.8 \mathrm{mmol}, 76 \%\right.$ for 3 steps) as a white solid: ${ }^{1} \mathrm{H}-\mathrm{NMR}$ $\left(\mathrm{CDCl}_{3}, 400 \mathrm{MHz}\right) \square 1.71-2.05(4 \mathrm{H}, \mathrm{m}), 2.35-2.51(6 \mathrm{H}, \mathrm{m}), 3.76(3 \mathrm{H}, \mathrm{s}), 6.73(1 \mathrm{H}, \mathrm{br}), 12.16(1 \mathrm{H}$, $\mathrm{s}) ;{ }^{13} \mathrm{C}-\mathrm{NMR}\left(\mathrm{CDCl}_{3}, 100 \mathrm{MHz}\right) \square 26.4,29.7,32.2,32.8,35.1,51.6,57.2,95.2,170.7,172.3,177.2$; IR (film) 3203, 3084, 2951, 1745, 1695, 1620, 1443, $1361 \mathrm{~cm}^{-1}$; HRMS (FAB) calcd for $\mathrm{C}_{11} \mathrm{H}_{16} \mathrm{NO}_{4}$ $226.1074\left[(\mathrm{M}+\mathrm{H})^{+}\right]$, found 226.1069 .

To a stirred solution of the above keto-ester $(1.66 \mathrm{~g}, 7.37 \mathrm{mmol})$ in $\mathrm{MeOH}(15 \mathrm{ml})$ at room temperature was added aqueous $4 \mathrm{~N} \mathrm{NaOH}(3.67 \mathrm{ml}, 14.7 \mathrm{mmol})$. The reaction mixture was stirred at $100{ }^{\circ} \mathrm{C}$ for 3.5 hours. After the reaction mixture was cooled to room temperature, small amount of methyl orange was added, and was neutralized with aqueous $12 \mathrm{~N} \mathrm{HCl}$ carefully. The solvent was removed under reduced pressure and the resulting crude product of 6 was used in the next reaction without further purification: ${ }^{1} \mathrm{H}-\mathrm{NMR}\left(\mathrm{CDCl}_{3}, 400 \mathrm{MHz}\right) \square 1.93-2.10(6 \mathrm{H}, \mathrm{m}), 2.36-2.61(6 \mathrm{H}, \mathrm{m})$, 8.34 (1H, br); ${ }^{13} \mathrm{C}-\mathrm{NMR}\left(\mathrm{CDCl}_{3}, 100 \mathrm{MHz}\right) \square 30.0,32.3,37.7,37.8,58.4$, 178.2, 209.6; IR (film) 3202, 1705, 1652, 1323, $1268 \mathrm{~cm}^{-1}$; HRMS (FAB) calcd for $\mathrm{C}_{9} \mathrm{H}_{13} \mathrm{NO}_{2} 167.0946\left(\mathrm{M}^{+}\right)$, found 167.0962. 
(2,8-Dioxo-1-aza-spiro[4.5]dec-1-yl)-acetaldehyde (7).

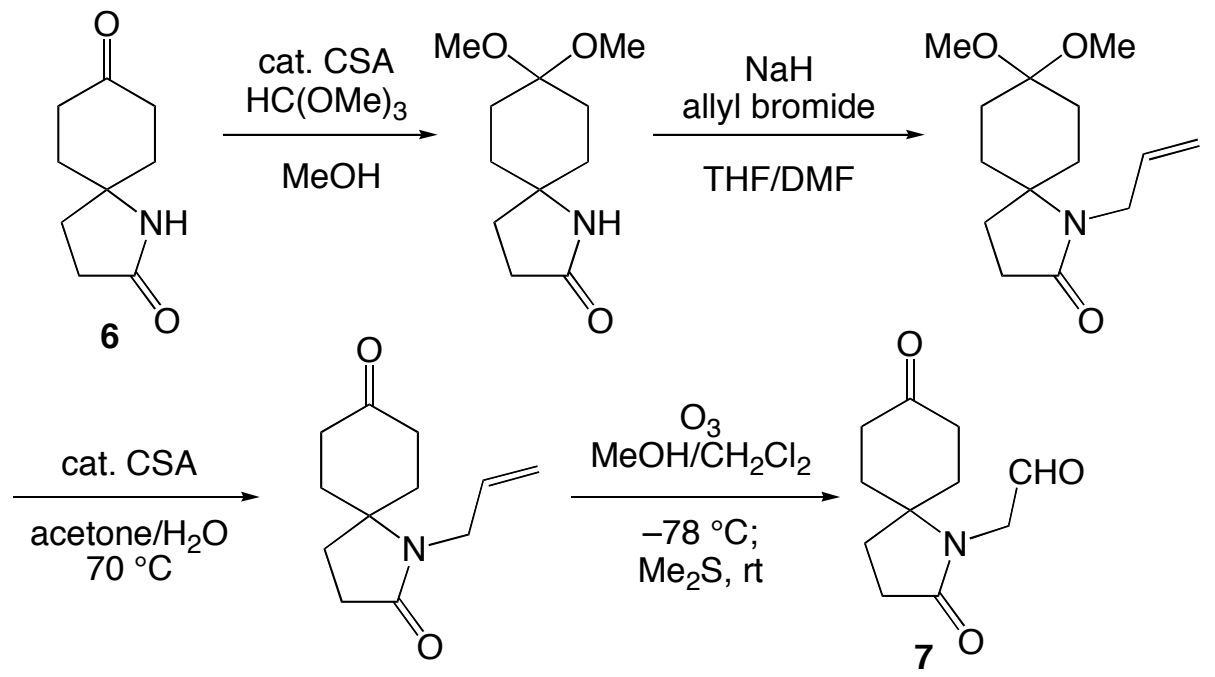

To a stirred solution of the above 6 (7.37 mmol as theoretical amount) in $\mathrm{MeOH}$ (15 ml) at room temperature was added $\mathrm{HC}(\mathrm{OMe})_{3}(0.964 \mathrm{ml}, 8.81 \mathrm{mmol})$ followed by CSA $(85.3 \mathrm{mg}, 0.367 \mathrm{mmol})$. After stirring at room temperature for $30 \mathrm{~min}$, the mixture was neutralized with $\mathrm{Et}_{3} \mathrm{~N}$. The solvent was removed under reduced pressure and the resulting crude product of the above dimethylacetal was used in the next reaction without further purification: ${ }^{1} \mathrm{H}-\mathrm{NMR}\left(\mathrm{CDCl}_{3}, 400 \mathrm{MHz}\right) \square 1.62-1.73$ $(8 \mathrm{H}, \mathrm{m}), 1.96(2 \mathrm{H}, \mathrm{t}, J=8.2 \mathrm{~Hz}), 2.40(2 \mathrm{H}, \mathrm{t}, J=8.2 \mathrm{~Hz}), 3.18(6 \mathrm{H}, \mathrm{s}), 6.36(1 \mathrm{H}, \mathrm{br}) ;{ }^{13} \mathrm{C}-\mathrm{NMR}$ $\left(\mathrm{CDCl}_{3}, 100 \mathrm{MHz}\right) \square 29.1,29.7,34.3,34.4,47.7,58.6,98.8,177.1$; IR (film) 3207, 2952, 1737, 1692, 1439, 1105, $1056 \mathrm{~cm}^{-1}$; HRMS (FAB) calcd for $\mathrm{C}_{10} \mathrm{H}_{16} \mathrm{NO}_{2} 182.1181$ [(M-OMe $)^{+}$], found 182.1197.

To a stirred solution of the above dimethylacetal $(7.37 \mathrm{mmol}$ as theoretical amount) in $3: 1$ THF/DMF $(15 \mathrm{ml})$ at room temperature was added $\mathrm{NaH}(861 \mathrm{mg}, 21.5 \mathrm{mmol})$. The mixture was stirred at room temperature for $10 \mathrm{~min}$ then allyl bromide $(1.40 \mathrm{ml}, 16.2 \mathrm{mmol})$ was added. After stirring at room temperature for 3.5 hours, saturated aqueous ammonium chloride was added and the mixture was extracted with AcOEt. The combined organic layer was dried over $\mathrm{MgSO}_{4}$. The solvent was removed under reduced pressure and the resulting crude product of the above lactam was used in the next reaction without further purification: ${ }^{1} \mathrm{H}-\mathrm{NMR}\left(\mathrm{CDCl}_{3}, 400 \mathrm{MHz}\right) \square 1.37(2 \mathrm{H}$, $\mathrm{d}, J=13.6 \mathrm{~Hz}), 1.48(2 \mathrm{H}, \mathrm{dt}, J=4.0,13.6 \mathrm{~Hz}), 1.84(2 \mathrm{H}, \mathrm{dt}, J=4.0,13.6 \mathrm{~Hz}), 1.96(2 \mathrm{H}, \mathrm{t}, J=4.0$ $\mathrm{Hz}), 2.03(2 \mathrm{H}, \mathrm{d}, J=13.6 \mathrm{~Hz}), 2.40(2 \mathrm{H}, \mathrm{t}, J=4.0 \mathrm{~Hz}), 3.18(3 \mathrm{H}, \mathrm{s}), 3.21(3 \mathrm{H}, \mathrm{s}), 3.82(2 \mathrm{H}, \mathrm{d}, J=$ $4.8 \mathrm{~Hz}), 5.10(1 \mathrm{H}, \mathrm{d}, J=9.6 \mathrm{~Hz}), 5.17(1 \mathrm{H}, \mathrm{d}, J=15.6 \mathrm{~Hz}), 5.80(1 \mathrm{H}, \mathrm{ddd}, J=4.8,9.6,15.6 \mathrm{~Hz})$; ${ }^{13} \mathrm{C}-\mathrm{NMR}\left(\mathrm{CDCl}_{3}, 100 \mathrm{MHz}\right) \square 28.9,29.0,29.1,31.2,41.7,47.6,47.9,63.5,98.5,116.1,134.7$, 173.6.

To a stirred solution of the above lactam $\left(7.37 \mathrm{mmol}\right.$ as theoretical amount) in $2: 1$ acetone $/ \mathrm{H}_{2} \mathrm{O}$ $(15 \mathrm{ml})$ at room temperature was added a catalytic amount of CSA (85.3 mg, $0.368 \mathrm{mmol})$. The reaction mixture was stirred at $70{ }^{\circ} \mathrm{C}$ for $30 \mathrm{~min}$. After the reaction mixture was cooled to room temperature, $\mathrm{Et}_{3} \mathrm{~N}(0.15 \mathrm{ml}, 1.08 \mathrm{mmol})$ was added. The soluvent was removed under reduced 
pressure to afford the above ketone $\left(1.14 \mathrm{~g}, 5.50 \mathrm{mmol}, 75 \%\right.$ for 4 steps) as white solid: ${ }^{1} \mathrm{H}-\mathrm{NMR}$ $\left(\mathrm{CDCl}_{3}, 400 \mathrm{MHz}\right) \square 1.80-1.85(2 \mathrm{H}, \mathrm{m}), 2.10-2.23(4 \mathrm{H}, \mathrm{m}), 2.40-2.57(6 \mathrm{H}, \mathrm{m}), 3.85(2 \mathrm{H}, \mathrm{d}, J=5.6$ $\mathrm{Hz}), 5.12(1 \mathrm{H}, \mathrm{d}, J=10.0 \mathrm{~Hz}), 5.17(1 \mathrm{H}, \mathrm{d}, J=18.4 \mathrm{~Hz}), 5.79(1 \mathrm{H}, \mathrm{ddd}, J=5.6,10.0,22.8 \mathrm{~Hz})$; ${ }^{13} \mathrm{C}-\mathrm{NMR}\left(\mathrm{CDCl}_{3}, 100 \mathrm{MHz}\right) \square 28.8,28.9,34.1,37.6,41.9,62.5,116.6,134.5,174.0$, 208.6; IR (film) 2938, 1717, 1685, 1404, 1324, 1226, $1151 \mathrm{~cm}^{-1}$; HRMS (FAB) calcd for $\mathrm{C}_{12} \mathrm{H}_{17} \mathrm{NO}_{2} 207.1259$ $\left(\mathrm{M}^{+}\right)$, found 207.1249.

Through a stirred solution of the above ketone $(5.30 \mathrm{~g}, 25.6 \mathrm{mmol})$ in $1: 1 \mathrm{MeOH} / \mathrm{CH}_{2} \mathrm{Cl}_{2}(50 \mathrm{ml})$ at $-78{ }^{\circ} \mathrm{C}$ was bubbled ozone gas. After the disappearance of starting material monitored by TLC, argon gas was bubbled and to this solution at $-78{ }^{\circ} \mathrm{C}$ was added $\mathrm{Me}_{2} \mathrm{~S}$ (18.8 ml, $\left.256 \mathrm{mmol}\right)$. After stirring for $30 \mathrm{~min}$, the solvent was removed under reduced pressure and the resulting crude product of 7 was used in the next reaction without further purification: ${ }^{1} \mathrm{H}-\mathrm{NMR}\left(\mathrm{CDCl}_{3}, 400 \mathrm{MHz}\right) \square 1.89$ $1.93(4 \mathrm{H}, \mathrm{m}), 2.32(2 \mathrm{H}, \mathrm{t}, J=8.0 \mathrm{~Hz}), 2.42-2.62(6 \mathrm{H}, \mathrm{m}), 3.96(2 \mathrm{H}, \mathrm{s}), 9.56(1 \mathrm{H}, \mathrm{s})$.

Hydroxyketone (8).
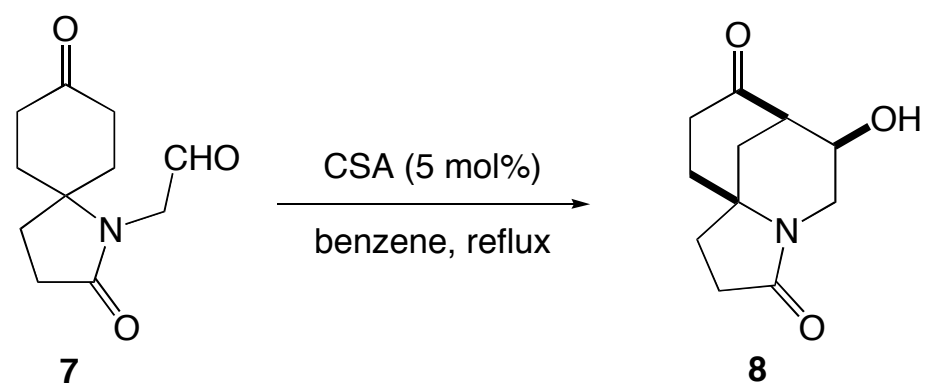

To a stirred solution of foregoing crude product of 7 (25.6 mmol as theoretical amount) in benzene $(50 \mathrm{ml})$ at room temperature was added a catalytic amount of CSA (297 $\mathrm{mg}, 1.28 \mathrm{mmol})$. The reaction mixture was heated to $90{ }^{\circ} \mathrm{C}$ for $5 \mathrm{~min}$. After the reaction mixture was cooled to room temperature, the mixture was filtered to give a white solid, which was washed with $\mathrm{Et}_{2} \mathrm{O}$ and dried in vacuo, to yield pure hydroxyketone 8 (4.30 g, $20.6 \mathrm{mmol}, 80 \%$ for 2 steps) as a white solid.: ${ }^{1} \mathrm{H}$ $\mathrm{NMR}\left(\mathrm{CDCl}_{3}, 400 \mathrm{MHz}\right) \square 1.82-2.25(6 \mathrm{H}, \mathrm{m}), 2.42-2.71(4 \mathrm{H}, \mathrm{m}), 2.90-2.96(2 \mathrm{H}, \mathrm{m}), 4.00(1 \mathrm{H}, \mathrm{m})$, $4.42(1 \mathrm{H}, \mathrm{dd}, J=7.3,13.7 \mathrm{~Hz}) ;{ }^{13} \mathrm{C}-\mathrm{NMR}\left(\mathrm{CDCl}_{3}, 100 \mathrm{MHz}\right) \square 30.0,31.7,35.4,37.4,38.9,43.8$, 51.7, 57.2, 66.9, 173.6, 210.7; IR (KBr) 3189, 2915, 1705, 1665, 1641, 1450, 1419, $1218,1087 \mathrm{~cm}-$ ${ }^{-1}$; HRMS (FAB) calcd for $\mathrm{C}_{11} \mathrm{H}_{16} \mathrm{NO}_{3} 210.1125\left[(\mathrm{M}+\mathrm{H})^{+}\right]$, found 210.1124 . 
Bis TBS ether (9).

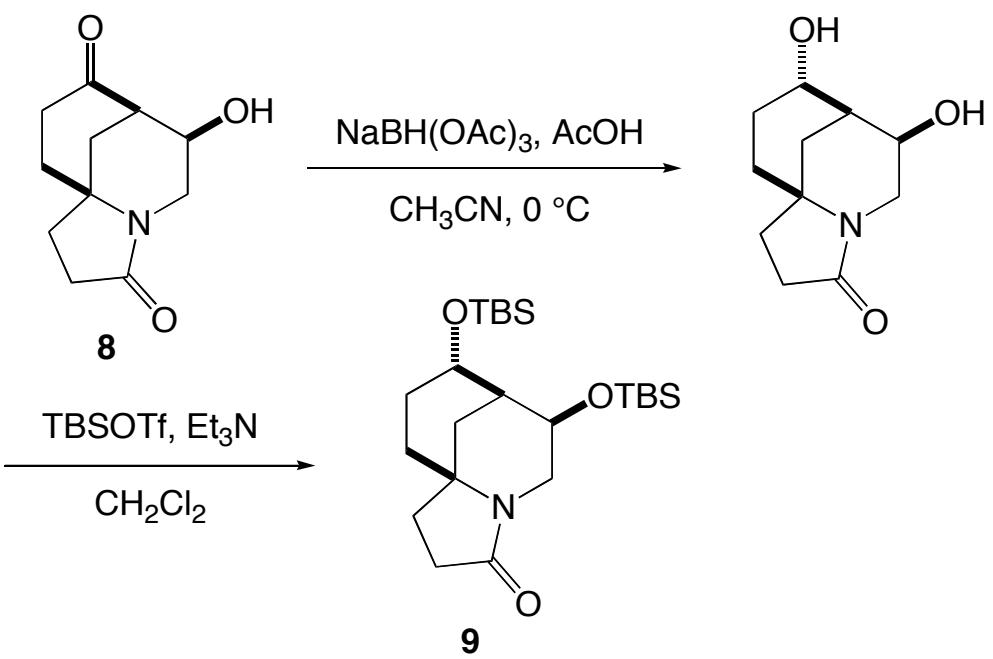

To a stirred mixture of $\mathrm{NaBH}(\mathrm{OAc})_{3}(72.0 \mathrm{~g}, 340 \mathrm{mmol}), \mathrm{CH}_{3} \mathrm{CN}(380 \mathrm{ml})$ and $\mathrm{AcOH}(77 \mathrm{ml})$ was added hydroxyketone $8(17.6 \mathrm{~g}, 84.1 \mathrm{mmol})$ at $0{ }^{\circ} \mathrm{C}$. After stirring at $0{ }^{\circ} \mathrm{C}$ for 2 hours, the mixture was warmed to room temperature where it was stirred for an additional 2 hours. The reaction mixture was filtered through a pad of Celite and the solvent was removed under reduced pressure. The resulting residue was purified by silica gel chromatography $\left(\mathrm{CH}_{2} \mathrm{Cl}_{2}: \mathrm{MeOH}=95: 5\right.$ 90:10) to afford crude product of the above diol, which was used in the next reaction without further purification.

To a stirred solution of foregoing crude product of the above diol $(84.1 \mathrm{mmol}$ as theoretical amount) in $\mathrm{CH}_{2} \mathrm{Cl}_{2}(250 \mathrm{ml})$ at room temperature was added $\mathrm{Et}_{3} \mathrm{~N}(94 \mathrm{ml}, 674 \mathrm{mmol})$ followed by TBSOTf $(57.5 \mathrm{ml}, 250 \mathrm{mmol})$. After stirring at room temperature for 2 hours, saturated aqueous ammonium chloride was added and the mixture was extracted with $\mathrm{CH}_{2} \mathrm{Cl}_{2}$. The combined organic layer was washed with brine then dried over $\mathrm{MgSO}_{4}$. The solvent was removed under reduced pressure then resulting residue was purified by silica gel chromatography (AcOEt:hexane=0:1-1:1) to afford crude product of $\mathbf{9}$, which was used in the next reaction without further purification. 
Ketone (10).

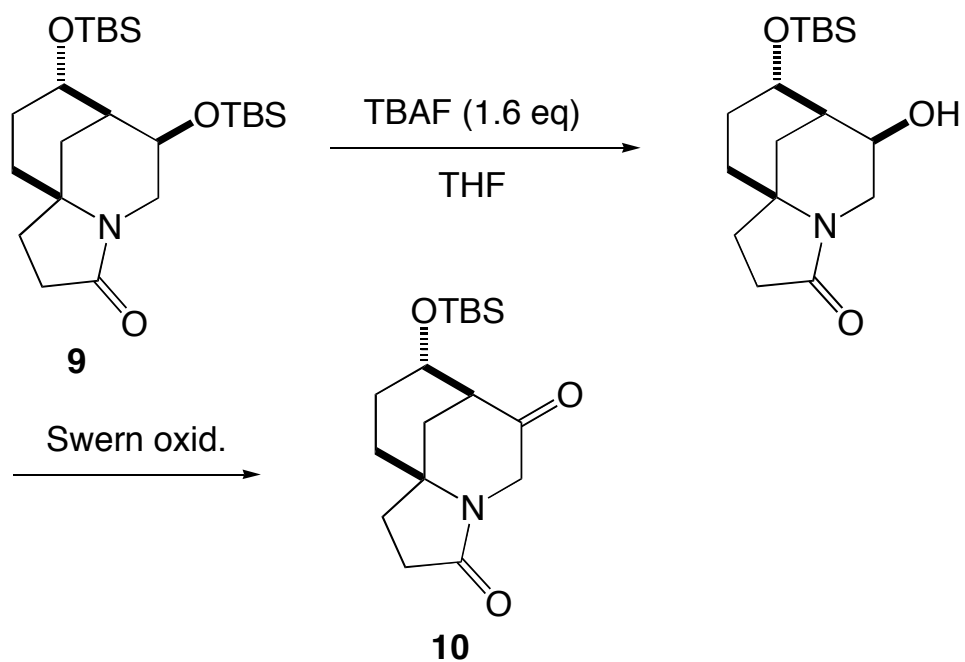

To a stirred solution of foregoing crude product of $\mathbf{9}(84.1 \mathrm{mmol}$ as theoretical amount $)$ in THF $(450 \mathrm{ml})$ at room temperature was added TBAF (1 M in THF)(134 ml, $134 \mathrm{mmol})$ slowly. After complete addition ( 2 hours), saturated aqueous ammonium chloride was added and the mixture was extracted with AcOEt. The combined organic layer was washed with brine then dried over $\mathrm{Na}_{2} \mathrm{SO}_{4}$. The solvent was removed under reduced pressure then resulting residue was purified by silica gel chromatography (AcOEt:hexane=0:1-9:1) to afford the above alcohol (26.6 g, $81.7 \mathrm{mmol}, 97 \%$ for 3 steps) as white solid: ${ }^{1} \mathrm{H}-\mathrm{NMR}\left(\mathrm{CDCl}_{3} \square 7.26,400 \mathrm{MHz}\right) \square 0.05(6 \mathrm{H}, \mathrm{s}), 0.88$ (9H, s), 1.67-2.00 $(6 \mathrm{H}, \mathrm{m}), 2.22-2.36(3 \mathrm{H}, \mathrm{m}), 2.44-2.52(1 \mathrm{H}, \mathrm{m}), 2.96(1 \mathrm{H}, \mathrm{br}), 3.04(1 \mathrm{H}, \mathrm{t}, J=11.9 \mathrm{~Hz}), 4.02(1 \mathrm{H}$, br), $4.18(1 \mathrm{H}, \mathrm{dd}, J=8.2,13.7 \mathrm{~Hz}), 4.28(1 \mathrm{H}, \mathrm{s}) ;{ }^{13} \mathrm{C}-\mathrm{NMR}\left(\mathrm{CDCl}_{3}, 100 \mathrm{MHz}\right) \square-4.9,18.0,25.8$, 30.1, 30.5, 32.9, 33.0, 34.1, 43.0, 45.0, 58.6, 64.4, 66.7, 173.8; IR (KBr) 3209, 2953, 2928, 1678, 1452, $1252 \mathrm{~cm}^{-1}$; HRMS (FAB) calcd for $\mathrm{C}_{17} \mathrm{H}_{31} \mathrm{NO}_{3} \mathrm{Si} 325.2073\left(\mathrm{M}^{+}\right)$, found 325.2065.

To a solution of oxalyl chloride $(0.398 \mathrm{ml}, 4.56 \mathrm{mmol})$ in $\mathrm{CH}_{2} \mathrm{Cl}_{2}(6 \mathrm{ml})$ at $-78{ }^{\circ} \mathrm{C}$ was added DMSO (0.485 ml, $6.83 \mathrm{mmol})$. After the resulting mixture was stirred for 1 hour, the above alcohol $(0.741 \mathrm{~g}, 2.28 \mathrm{mmol})$ in $\mathrm{CH}_{2} \mathrm{Cl}_{2}(4 \mathrm{ml})$ was added and the mixture was stirred for 30 min before $\mathrm{Et}_{3} \mathrm{~N}(1.27 \mathrm{ml}, 9.11 \mathrm{mmol})$ was added. The mixture was allowed to warm to room temperature. After stirring at room temperature for $30 \mathrm{~min}$, saturated aqueous ammonium chloride was added and the mixture was extracted with AcOEt. The combined organic layer was dried over $\mathrm{MgSO}_{4}$. The solvent was removed under reduced pressure then resulting residue was purified by silica gel chromatography (AcOEt:hexane=1:2-1:1) to afford the pure ketone 10 (620 mg, $1.92 \mathrm{mmol}, 84 \%$ ) as white solid.: ${ }^{1} \mathrm{H}-\mathrm{NMR}\left(\mathrm{CDCl}_{3} \square 7.26,400 \mathrm{MHz}\right) \square 0.07(6 \mathrm{H}, \mathrm{s}), 0.89$ (9H, s), 1.48-1.57 (1H, m), 1.70-2.05 (6H, m), 2.34-2.40 (1H, m), 2.48-2.52 (1H, m), 2.57-2.66 (1H, m), $2.72(1 \mathrm{H}, \mathrm{s}), 3.99(1 \mathrm{H}$, $\mathrm{d}, J=22.0 \mathrm{~Hz}), 4.00(1 \mathrm{H}, \mathrm{d}, J=3.7 \mathrm{~Hz}), 4.20(1 \mathrm{H}, \mathrm{d}, J=22.0 \mathrm{~Hz}) ;{ }^{13} \mathrm{C}-\mathrm{NMR}\left(\mathrm{CDCl}_{3}, 100 \mathrm{MHz}\right) \square$ -5.1, 18.0, 25.6, 29.2, 30.1, 31.1, 32.1, 34.2, 52.0, 52.4, 58.6, 67.2, 174.0, 205.7; IR (film) 2933, 2894, 2857, 1711, 1688, 1411, $1255 \mathrm{~cm}^{-1}$; HRMS (FAB) calcd for $\mathrm{C}_{17} \mathrm{H}_{30} \mathrm{NO}_{3} \mathrm{Si} 324.1995\left[(\mathrm{M}+\mathrm{H})^{+}\right]$, found 324.1981. 
Ketone (11).
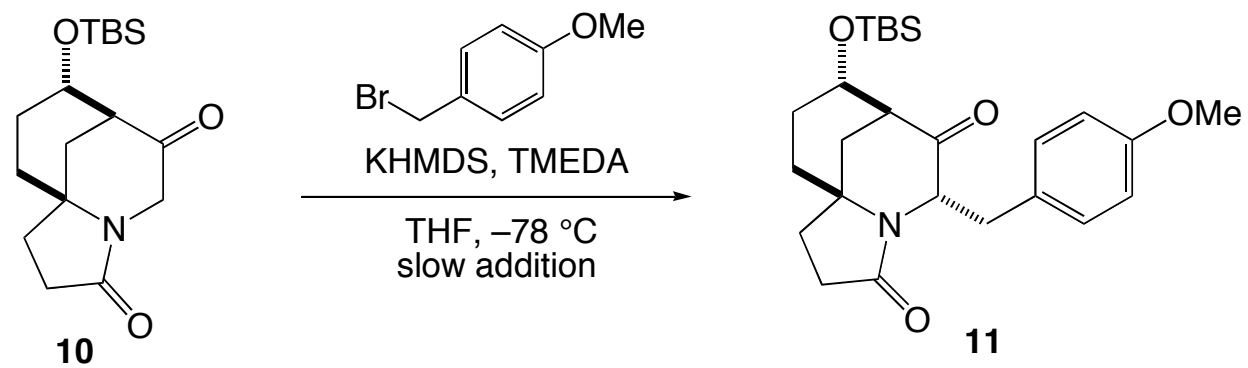

To a solution of $10(17.3 \mathrm{~g}, 53.5 \mathrm{mmol})$ in THF $(540 \mathrm{ml})$ at $-78{ }^{\circ} \mathrm{C}$ were added TMEDA $(40.3 \mathrm{ml}$, $267 \mathrm{mmol})$ and KHMDS (0.5 $\mathrm{M}$ in toluene), $(110.2 \mathrm{ml}, 55.1 \mathrm{mmol})$. After stirring at $-78{ }^{\circ} \mathrm{C}$ for 30 min, p-methoxybenzylbromide $(30.0 \mathrm{ml}, 160 \mathrm{mmol})$ in THF $(200 \mathrm{ml})$ was added slowly. After complete addition (10 hours), the reaction mixture was allowed to warm to room temperature and then, saturated aqueous ammonium chloride was added. The mixture was extracted with AcOEt. The combined organic layer was washed with brine then dried over $\mathrm{Na}_{2} \mathrm{SO}_{4}$. The solvent was removed under reduced pressure then resulting residue was purified by silica gel chromatography (AcOEt:hexane=1:9-2:8) to afford $11(15.2 \mathrm{~g}, 34.2 \mathrm{mmol}, 64 \%)$ as colorless oil.: ${ }^{1} \mathrm{H}-\mathrm{NMR}\left(\mathrm{CDCl}_{3} \square\right.$ 7.26, $400 \mathrm{MHz}) \square 0.03(6 \mathrm{H}, \mathrm{s}), 0.84(9 \mathrm{H}, \mathrm{s}), 1.23-1.34(2 \mathrm{H}, \mathrm{m}), 1.46-1.59$ (3H, m), 1.71-1.89 (2H, m), $2.26(1 \mathrm{H}, \mathrm{s}), 2.38-2.44(1 \mathrm{H}, \mathrm{m}), 2.57-2.67(1 \mathrm{H}, \mathrm{m}), 3.10(1 \mathrm{H}, \mathrm{dd}, J=2.7,13.7 \mathrm{~Hz}), 3.77(3 \mathrm{H}, \mathrm{s})$, $3.80(2 \mathrm{H}, \mathrm{m}), 3.92(1 \mathrm{H}, \mathrm{m}), 4.54(1 \mathrm{H}, \mathrm{d}, J=2.7 \mathrm{~Hz}), 6.78(2 \mathrm{H}, \mathrm{d}, J=9.2 \mathrm{~Hz}), 6.88(2 \mathrm{H}, \mathrm{d}, J=8.2$ $\mathrm{Hz}) ;{ }^{13} \mathrm{C}-\mathrm{NMR}\left(\mathrm{CDCl}_{3}, 100 \mathrm{MHz}\right) \square-5.1,17.9,25.6,27.0,28.9,30.9,31.5,34.1,35.3,51.8,55.2$, 59.4, 64.2, 68.0, 113.8, 128.7, 130.8, 158.7, 174.5, 210.0; IR (film) 2935, 2857, 1713, 1689, 1513, 1396, 1252, $1029 \mathrm{~cm}^{-1}$; HRMS (FAB) calcd for $\mathrm{C}_{25} \mathrm{H}_{38} \mathrm{NO}_{4} \mathrm{Si} 444.2570\left[(\mathrm{M}+\mathrm{H})^{+}\right]$, found 444.2565.

Bis TBS ether (12).

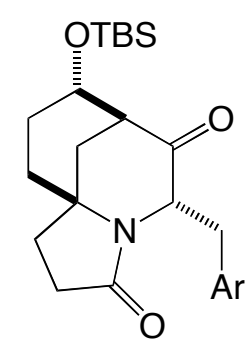

11

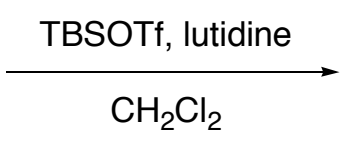

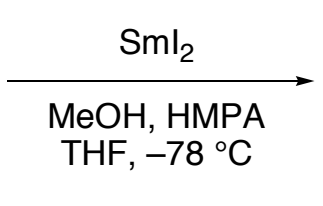

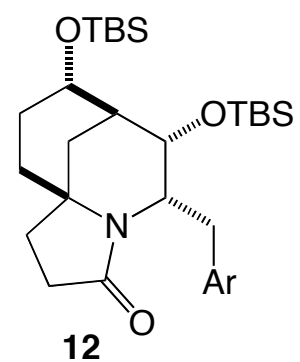

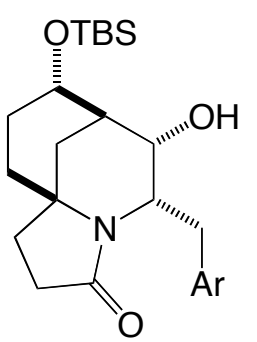

The solution of $\mathrm{SmI}_{2}$ in THF was freshly prepared by addition of diiodomethane $(6.08 \mathrm{ml}, 75.7$ mmol) to a suspension of $\mathrm{Sm}(13.6 \mathrm{~g}, 90.6 \mathrm{mmol})$ in THF $(725 \mathrm{ml})$ and stirring at room temperature 
for 9 hours. To the above solution of $\mathrm{SmI}_{2}$ in THF, a degassed mixture of $\mathrm{MeOH}(6.12 \mathrm{ml}, 151$ mmol), HMPA (65.8 ml, $378 \mathrm{mmol})$ and THF (70 ml) was added. To the mixture, 11(6.63 $\mathrm{g}, 15.1$ mmol $)$ in degassed THF $(100 \mathrm{ml})$ was added dropwise at $-78{ }^{\circ} \mathrm{C}$ and the reaction was left to stir overnight. Saturated aqueous sodium bicarbonate was added at room temperature and the mixture was extracted with AcOEt. The combined organic layer was washed with brine then dried over $\mathrm{MgSO}_{4}$. The solvent was removed under reduced pressure then resulting residue was purified by silica gel chromatography (AcOEt:hexane=1:9-6:4) to afford the alcohol containing inseparable HMPA, which was used in the next reaction without further purification.

To a stirred solution of the foregoing crude alcohol (34.9 mmol as theoretical amount) in $\mathrm{CH}_{2} \mathrm{Cl}_{2}$ $(174 \mathrm{ml})$ at room temperature was added 2,6-lutidine $(12.2 \mathrm{ml}, 105 \mathrm{mmol})$ followed by TBSOTf $(14.9 \mathrm{ml}, 69.6 \mathrm{mmol})$. After stirring at room temperature for 2.5 hours, saturated aqueous ammonium chloride was added and the mixture was extracted with $\mathrm{CH}_{2} \mathrm{Cl}_{2}$. The combined organic layer was dried over $\mathrm{MgSO}_{4}$. The solvent was removed under reduced pressure then resulting residue was purified by silica gel chromatography (AcOEt:hexane=5:95-3:7) to afford the bis TBS ether 12 (16.6 g, $29.7 \mathrm{mmol}, 85 \%$ for 2 steps) as pale yellow oil.: ${ }^{1} \mathrm{H}-\mathrm{NMR}\left(\mathrm{CDCl}_{3} \square 7.26,400\right.$ $\mathrm{MHz}) \square-0.01-0.02$ (12H, m), 0.86 (9H, s), 0.92 (9H, s), 1.55-1.95 (6H, m), 2.03 (1H, s), 2.25-2.43 (2H, m), 3,07-3.13 (1H, m), $3.63(1 \mathrm{H}, \mathrm{m}), 3.77(1 \mathrm{H}, \mathrm{s}), 3.78(3 \mathrm{H}, \mathrm{s}), 3.82-3.87(1 \mathrm{H}, \mathrm{m}), 4.04-4.09$ $(1 \mathrm{H}, \mathrm{m}), 6.81(2 \mathrm{H}, \mathrm{d}, J=9.2 \mathrm{~Hz}), 7.21(2 \mathrm{H}, \mathrm{d}, J=8.2 \mathrm{~Hz}) ;{ }^{13} \mathrm{C}-\mathrm{NMR}\left(\mathrm{CDCl}_{3}, 100 \mathrm{MHz}\right) \square-5.0$, $-4.9,-4.7,-4.1,18.0,18.3,25.7,25.9,27.2,29.5,31.1,32.1,33.7,34.0,45.3,55.2,58.5,60.6,67.5$, 69.3, 113.5, 130.2, 132.6, 157.7, 176.1; IR (film) 2953, 2930, 2857, 1693, 1513, 1250, 1077, 1053 $\mathrm{cm}^{-1}$; HRMS (FAB) calcd for $\mathrm{C}_{31} \mathrm{H}_{53} \mathrm{NO}_{4} \mathrm{Si}_{2} 559.3513\left(\mathrm{M}^{+}\right)$, found 559.3528.

Carboxylic acid (13).
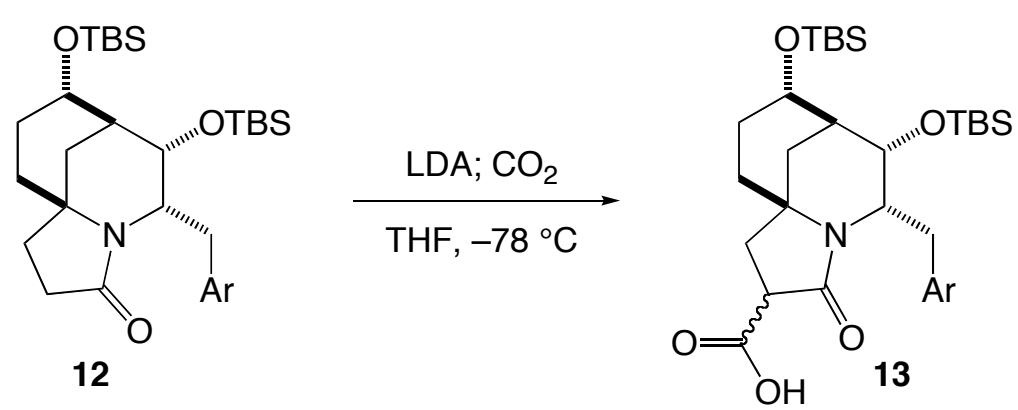

To a solution of diisopropylamine $(1.20 \mathrm{ml}, 8.56 \mathrm{mmol})$ in THF $(10 \mathrm{ml})$ was added $n$-BuLi (1.59 $\mathrm{M}$ in hexane $)(4.38 \mathrm{ml}, 6.96 \mathrm{mmol})$ at $-78{ }^{\circ} \mathrm{C}$, the resulting solution was stirred at $0{ }^{\circ} \mathrm{C}$ for $20 \mathrm{~min}$ before it was cooled to $-78{ }^{\circ} \mathrm{C}$. To the solution was added a solution of 12 (321 $\left.\mathrm{mg}, 0.573 \mathrm{mmol}\right)$ in THF $(1.5 \mathrm{ml})$ by dropwise. After stirring for 1 hour at $-78{ }^{\circ} \mathrm{C}$, crashed dry-ice blocks were added until remaining dry-ice solids were observed. After stirring at $-78{ }^{\circ} \mathrm{C}$ for $20 \mathrm{~min}$, saturated aqueous ammonium chloride was added and the mixture was extracted with AcOEt (7 times) and $\mathrm{CH}_{2} \mathrm{CH}_{2}$ (6 times). The combined organic layer was dried over $\mathrm{Na}_{2} \mathrm{SO}_{4}$. The solvent was removed under 
reduced pressure then resulting residue was washed with hexane and filtered over a pad of Celite. The filtrate was concentrated under reduced pressure to give crude product of 13, which was used in the next reaction without further purification: $\mathrm{MS}(\mathrm{FAB}) m / z 604\left(\mathrm{M}^{+}+1\right), 582,482,450$.

Oxime (14).

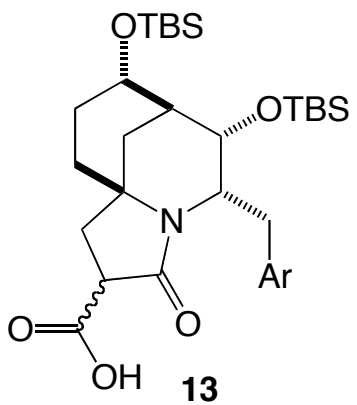
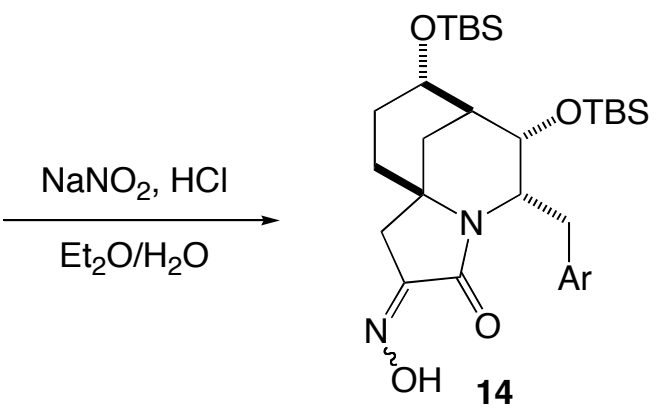

To a stirred solution of the above 13 in $5: 1 \mathrm{Et}_{2} \mathrm{O} / \mathrm{H}_{2} \mathrm{O}(2.4 \mathrm{ml})$ at $0{ }^{\circ} \mathrm{C}$ was added $\mathrm{NaNO}_{2}(400 \mathrm{mg}$, $5.8 \mathrm{mmol})$ followed by conc. $\mathrm{HCl}(0.25 \mathrm{ml}, 3.00 \mathrm{mmol})$ cautiously in four portions for 3 hours. After stirring at room temperature for 2.5 hours, saturated aqueous ammonium chloride was added and stirred for an additional 1 hour. The mixture was extracted with AcOEt and $\mathrm{CH}_{2} \mathrm{CH}_{2}$ (4 times). The combined organic layer was dried over $\mathrm{MgSO}_{4}$. The solvent was removed under reduced pressure then resulting residue was purified by PTLC (AcOEt:hexane=3:2 x2) to afford the oxime 14 (12.6 mg, $21.4 \square \mathrm{mol}, 57 \%$ for 2 steps) as pale orange solid: ${ }^{1} \mathrm{H}-\mathrm{NMR}\left(\mathrm{CDCl}_{3} \square 7.26,400 \mathrm{MHz}\right) \square 0.01$ $0.04(12 \mathrm{H}, \mathrm{m}), 0.86(9 \mathrm{H}, \mathrm{s}), 0.92(9 \mathrm{H}, \mathrm{s}), 1.60-2.08(7 \mathrm{H}, \mathrm{m}), 2.56(2 \mathrm{H}, \mathrm{q}, J=18.0 \mathrm{~Hz}), 3.12(1 \mathrm{H}, \mathrm{dd}$, $J=9.2,15.6 \mathrm{~Hz}), 3.65(1 \mathrm{H}, \mathrm{s}), 3.78(3 \mathrm{H}, \mathrm{s}), 4.11-4.18(2 \mathrm{H}, \mathrm{m}), 6.82(2 \mathrm{H}, \mathrm{d}, J=8.2 \mathrm{~Hz}), 7.20(2 \mathrm{H}, \mathrm{d}$, $J=8.2 \mathrm{~Hz}), 9.42(1 \mathrm{H}, \mathrm{br}) ;{ }^{13} \mathrm{C}-\mathrm{NMR}\left(\mathrm{CDCl}_{3}, 100 \mathrm{MHz}\right) \square-5.0,-4.9,-4.8,-4.1,18.0,18.3,25.7$, 26.0, 28.8, 30.2, 32.7, 33.5, 37.1, 45.2, 55.2, 57.9, 60.1, 66.7, 68.9, 113.7, 130.0, 131.9, 152.8, 157.8, 163.9; IR (film) 3269, 2953, 2930, 2857, 1708, 1660, 1513, $1251 \mathrm{~cm}^{-1}$; HRMS (FAB) calcd for $\mathrm{C}_{31} \mathrm{H}_{52} \mathrm{~N}_{2} \mathrm{O}_{5} \mathrm{Si}_{2} 588.3415\left(\mathrm{M}^{+}\right)$, found 588.3410.

Amine (15).
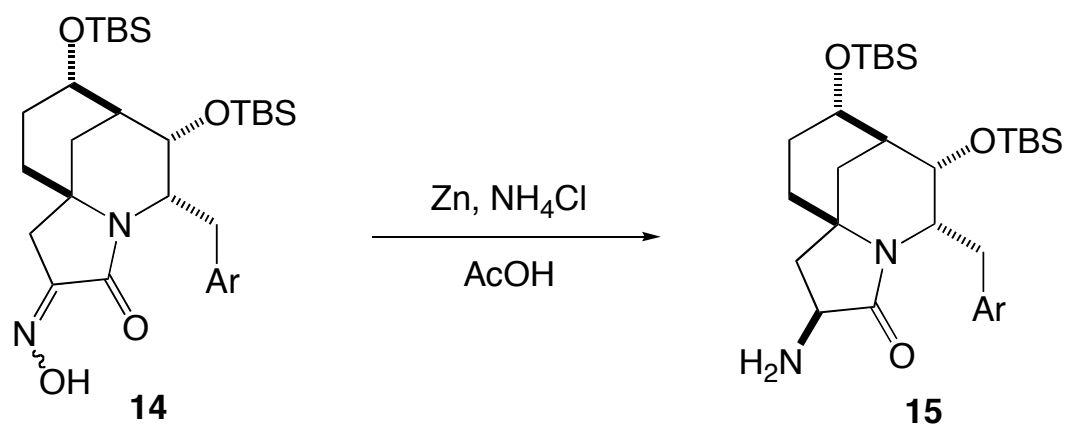

To a stirred solution of oxime $14(526 \mathrm{mg}, 0.893 \mathrm{mmol})$ in $\mathrm{AcOH}(20 \mathrm{ml})$ at room temperature was added activated zinc dust $(2.30 \mathrm{~g}, 35.2 \mathrm{mmol})$ and $\mathrm{NH}_{4} \mathrm{Cl}$ (ca.1.00 g, $\left.18.7 \mathrm{mmol}\right)$. After stirring at $50{ }^{\circ} \mathrm{C}$ overnight, the mixture was filtered over a pad of Celite and the filtrate was concentrated 
under reduced pressure. To the resulting residue, was added saturated aqueous sodium bicarbonate and the mixture was extracted with $\mathrm{CH}_{2} \mathrm{CH}_{2}$. The combined organic layer was dried over $\mathrm{Na}_{2} \mathrm{SO}_{4}$. The solvent was removed under reduced pressure then resulting residue was purified by silica gel chromatography (AcOEt:hexane=1:1-MeOH: $\left.\mathrm{CH}_{2} \mathrm{Cl}_{2}=1: 9\right)$ to afford the amine 15 (406 $\mathrm{mg}, 0.706$ mmol, 79\%) as pale orange solid.: ${ }^{1} \mathrm{H}-\mathrm{NMR}\left(\mathrm{CDCl}_{3} \square 7.26,400 \mathrm{MHz}\right) \square-0.02-0.06(12 \mathrm{H}, \mathrm{m}), 0.85$ $(9 \mathrm{H}, \mathrm{s}), 0.93(9 \mathrm{H}, \mathrm{s}), 1.61-2.07(10 \mathrm{H}, \mathrm{m}), 2.21(1 \mathrm{H}, \mathrm{m}), 3.13(1 \mathrm{H}, \mathrm{dd}, J=7.3,14.6 \mathrm{~Hz}), 3.46(1 \mathrm{H}$, $\mathrm{dd}, J=8.7,10.5 \mathrm{~Hz}), 3.51(1 \mathrm{H}, \mathrm{s}), 3.70(1 \mathrm{H}, \mathrm{br}), 3.79(3 \mathrm{H}, \mathrm{s}), 3.87(1 \mathrm{H}, \mathrm{t}, J=6.9 \mathrm{~Hz}), 3.98(2 \mathrm{H}, \mathrm{dd}$, $J=6.4,14.7 \mathrm{~Hz}), 6.83(2 \mathrm{H}, \mathrm{d}, J=8.2 \mathrm{~Hz}), 7.19(2 \mathrm{H}, \mathrm{d}, J=8.2 \mathrm{~Hz}) ;{ }^{13} \mathrm{C}-\mathrm{NMR}\left(\mathrm{CDCl}_{3}, 100 \mathrm{MHz}\right) \square$ $-5.0,-4.9,-4.8,-4.0,18.0,18.1,25.7,25.8,26.4,30.2,32.6,33.5,42.7,45.4,52.6,55.2,57.2,59.3$, 67.2, 69.5, 113.7, 129.7, 132.4, 157.8, 176.7; IR (film) 2952, 2930, 2857, 1697, 1513, 1250, 1078, $1050 \mathrm{~cm}^{-1}$; HRMS (FAB) calcd for $\mathrm{C}_{31} \mathrm{H}_{55} \mathrm{~N}_{2} \mathrm{O}_{4} \mathrm{Si}_{2} 575.3700\left[(\mathrm{M}+\mathrm{H})^{+}\right]$, found 575.3728 .

Carbamate (16).

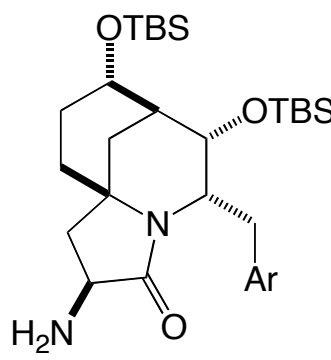

15

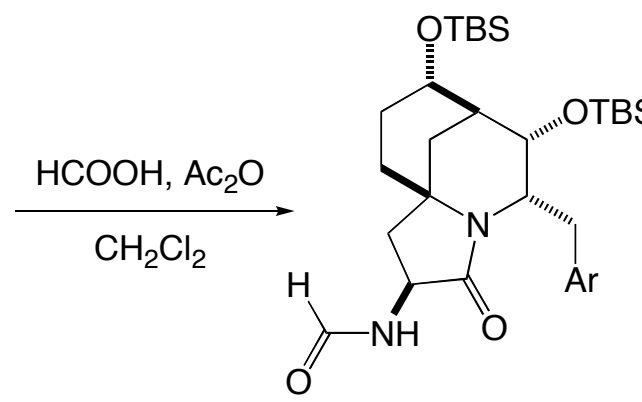

OTBS<smiles>CN[C@H]1CN2[C@@H](C[Al])[C@@H](O)[C@H]3C[C@]2(CC[C@@H]3[OH2+])C1</smiles>

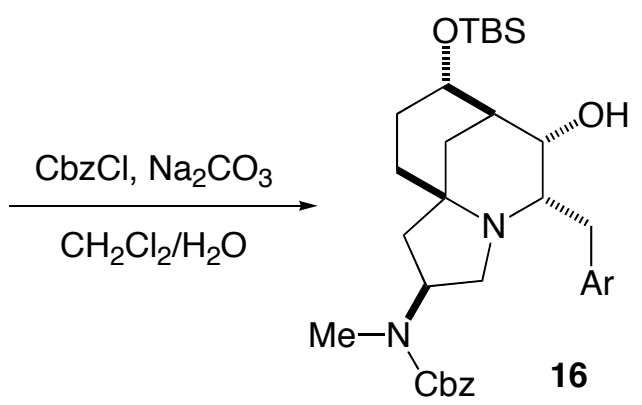

To a stirred solution of $15(13.4 \mathrm{mg}, 23.3 \square \mathrm{mol})$ in $\mathrm{CH}_{2} \mathrm{Cl}_{2}(2.0 \mathrm{ml})$ at $0{ }^{\circ} \mathrm{C}$ was added the mixture $(0.2 \mathrm{ml})$ of $\mathrm{HCOOH}(1.3 \mathrm{ml}, 34 \mathrm{mmol})$ and $\mathrm{Ac}_{2} \mathrm{O}(0.80 \mathrm{ml}, 8.5 \mathrm{mmol})$ dropwise. After stirring at $0{ }^{\circ} \mathrm{C}$ for $10 \mathrm{~min}$, the reaction mixture was warmed to room temperature and was added small amount of toluene. The solvent was removed under reduced pressure to give crude product of the above formamide, this unstable product was used in the next reaction without purification: ${ }^{1} \mathrm{H}$ NMR $\left(\mathrm{CDCl}_{3} \square 7.26,400 \mathrm{MHz}\right) \square-0.01-0.06(12 \mathrm{H}, \mathrm{m}), 0.85(9 \mathrm{H}, \mathrm{s}), 0.92(9 \mathrm{H}, \mathrm{s}), 1.57-2.10(10 \mathrm{H}$, m), $2.61(1 \mathrm{H}, \mathrm{dd}, J=8.2,12.8 \mathrm{~Hz}), 3.09(1 \mathrm{H}, \mathrm{dd}, J=10.1,17.4 \mathrm{~Hz}), 3.53(1 \mathrm{H}, \mathrm{d}, J=2.7 \mathrm{~Hz}), 3.70$ $(1 \mathrm{H}, \mathrm{br}), 3.79(3 \mathrm{H}, \mathrm{s}), 3.90-3.96(2 \mathrm{H}, \mathrm{m}), 4.36(1 \mathrm{H}, \mathrm{q}, J=6.4 \mathrm{~Hz}), 6.39(1 \mathrm{H}, \mathrm{br}), 6.84(2 \mathrm{H}, \mathrm{d}, J=$ $8.2 \mathrm{~Hz}), 7.18(2 \mathrm{H}, \mathrm{d}, J=9.2 \mathrm{~Hz}), 8.19(1 \mathrm{H}, \mathrm{s}) ;{ }^{13} \mathrm{C}-\mathrm{NMR}\left(\mathrm{CDCl}_{3}, 100 \mathrm{MHz}\right) \square-4.9,-4.9,-4.8,-4.0$, 18.0, 18.1, 25.7, 25.8, 25.9, 30.1, 32.2, 33.6, 41.4, 45.2, 50.8, 55.2, 58.6, 59.4, 67.1, 69.5, 113.8, 129.6, 131.9, 157.9, 161.7, 172.2; IR (film) 3286, 2952, 2931, 2857, 1677, 1541, 1250, 1078, 1051 $\mathrm{cm}^{-1}$; HRMS (FAB) calcd for $\mathrm{C}_{32} \mathrm{H}_{55} \mathrm{~N}_{2} \mathrm{O}_{5} \mathrm{Si}_{2} 603.3644\left[(\mathrm{M}+\mathrm{H})^{+}\right]$, found 603.3618. 
To a stirred solution of foregoing crude product of the above formamide (23.0 $\square \mathrm{mol}$ as theoretical amount) in THF $(2.0 \mathrm{ml})$ at $0{ }^{\circ} \mathrm{C}$ was added $\mathrm{LAH}(28.0 \mathrm{mg}, 0.740 \mathrm{mmol})$. After stirring at $50{ }^{\circ} \mathrm{C}$ overnight, water (28 $\square$ l), 15\% aqueous sodium hydroxide (28 $\square$ l), water (84 $\square \mathrm{l}$ ) and sufficient amount of $\mathrm{Et}_{2} \mathrm{O}$ was added at room temperature successively. After stirring for $30 \mathrm{~min}$, the mixture was filtered over a pad of Celite and the filtrate was concentrated under reduced pressure to give the crude methylamine, this polar product was used in the next reaction without purification.

To a stirred solution of the foregoing crude methylamine $(23.0 \square \mathrm{mol}$ as theoretical amount) in $3: 1$ $\mathrm{CH}_{2} \mathrm{Cl}_{2} / \mathrm{H}_{2} \mathrm{O}(2.4 \mathrm{ml})$ at room temperature was added $\mathrm{Na}_{2} \mathrm{CO}_{3}(25.0 \mathrm{mg}, 236 \square \mathrm{mol})$ followed by $\mathrm{CbzCl}(15.0 \square \mathrm{l}, 105 \square \mathrm{mol})$. After stirring at room temperature for 1 hour, saturated aqueous ammonium chloride was added and the mixture was extracted with $\mathrm{CH}_{2} \mathrm{CH}_{2}$. The combined organic layer was dried over $\mathrm{Na}_{2} \mathrm{SO}_{4}$. The solvent was removed under reduced pressure then resulting residue was purified by PTLC (AcOEt:hexane=1:1 x2) to afford pure alcohol 16 (11.5 mg, 19.3 $\square \mathrm{mol}, 84 \%$ for 3 steps) as pale yellow oil.: ${ }^{1} \mathrm{H}-\mathrm{NMR}\left(\mathrm{CDCl}_{3} \square 7.26,400 \mathrm{MHz}\right) \square-0.03-0.02(6 \mathrm{H}$, m), $0.85(9 \mathrm{H}, \mathrm{s}), 1.43-2.02(8 \mathrm{H}, \mathrm{m}), 2.71-2.75(1 \mathrm{H}, \mathrm{m}), 2.82(3 \mathrm{H}, \mathrm{s}), 3.23(1 \mathrm{H}, \mathrm{br}), 3.45(2 \mathrm{H}, \mathrm{br})$, $3.71(1 \mathrm{H}, \mathrm{s}), 3.79(3 \mathrm{H}, \mathrm{s}), 4.82(1 \mathrm{H}, \mathrm{br}), 5.11(2 \mathrm{H}, \mathrm{d}, 2.7 \mathrm{~Hz}), 6.83(2 \mathrm{H}, \mathrm{d}, J=9.2 \mathrm{~Hz}), 7.20(2 \mathrm{H}, \mathrm{d}$, $J=9.2 \mathrm{~Hz}), 7.31-7.36(5 \mathrm{H}, \mathrm{m}) ;{ }^{13} \mathrm{C}-\mathrm{NMR}\left(\mathrm{CD}_{3} \mathrm{CN} \square 118.2,100 \mathrm{MHz}\right) \square-4.6,-4.5,18.6,23.3,26.3$, 29.3, 31.5, 31.8, 36.3, 44.4, 46.9, 51.3, 52.7, 55.7, 58.6, 59.6, 67.4, 68.6, 114.4, 128.5, 128.7, 129.4, 131.1, 132.7, 138.4, 156.8, 158.8; IR (film) 3448, 2952, 2931, 1698, 1512, 1329, 1249, 1161, 1041 $\mathrm{cm}^{-1}$; HRMS (FAB) calcd for $\mathrm{C}_{34} \mathrm{H}_{51} \mathrm{~N}_{2} \mathrm{O}_{5} \mathrm{Si} 595.3562\left[(\mathrm{M}+\mathrm{H})^{+}\right]$, found 595.3531.

Dibenzyl phosphate (17).

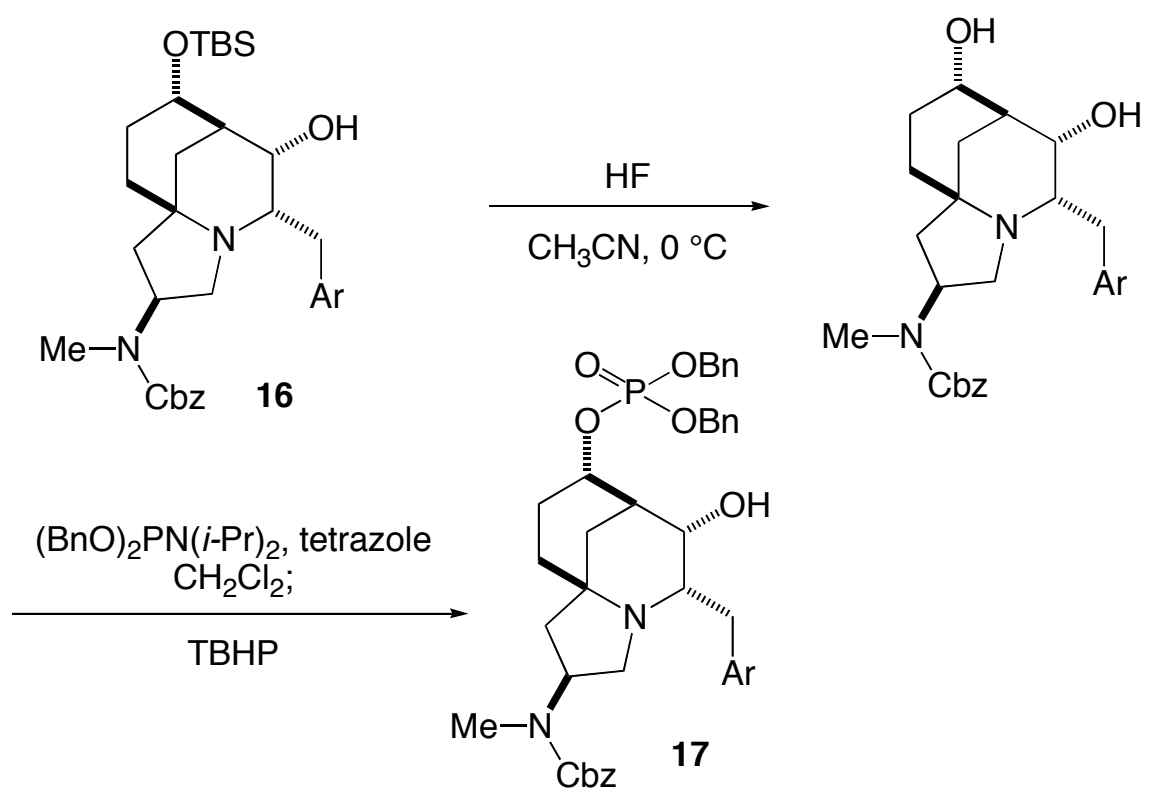

To a stirred solution of alcohol $16(179 \mathrm{mg}, 0.301 \mathrm{mmol})$ in $\mathrm{CH}_{3} \mathrm{CN}(9 \mathrm{ml})$ at $0{ }^{\circ} \mathrm{C}$ was added $48 \%$ aqueous $\mathrm{HF}(2.0 \mathrm{ml})$. After stirring at $0{ }^{\circ} \mathrm{C}$ for 5 hours, the reaction mixture was diluted with $\mathrm{CH}_{2} \mathrm{Cl}_{2}$ and was added saturated aqueous sodium bicarbonate. The mixture was extracted with 
$\mathrm{CH}_{2} \mathrm{Cl}_{2}$ (3 times) and $\mathrm{CHCl}_{3}$ (3 times), and the combined organic layer was dried over $\mathrm{Na}_{2} \mathrm{SO}_{4}$. The solvent was removed under reduced pressure then resulting residue was purified by silica gel chromatography (AcOEt:hexane=3:1-MeOH: $\left.\mathrm{CH}_{2} \mathrm{Cl}_{2}=1: 9\right)$ to afford the diol (127 $\mathrm{mg}, 0.264 \mathrm{mmol}$, $88 \%)$ as white foam.: ${ }^{1} \mathrm{H}-\mathrm{NMR}\left(\mathrm{CD}_{3} \mathrm{CN} \square 1.93,400 \mathrm{MHz}\right) \square 1.35-2.25(9 \mathrm{H}, \mathrm{m}), 2.55-2.59(8 \mathrm{H}, \mathrm{m})$, $3.30(1 \mathrm{H}, \mathrm{br}), 3.49(2 \mathrm{H}, \mathrm{br}), 3.68(1 \mathrm{H}, \mathrm{br}), 3.73(3 \mathrm{H}, \mathrm{s}), 4.69(1 \mathrm{H}, \mathrm{br}), 5.04(2 \mathrm{H}, \mathrm{s}), 6.82(2 \mathrm{H}, \mathrm{d}, J=$ $8.2 \mathrm{~Hz}), 7.22(2 \mathrm{H}, \mathrm{d}, J=9.2 \mathrm{~Hz}), 7.35(5 \mathrm{H}, \mathrm{s}) ;{ }^{13} \mathrm{C}-\mathrm{NMR}\left(\mathrm{CD}_{3} \mathrm{CN} \square 118.2,100 \mathrm{MHz}\right) \square 29.3,29.7$, 35.7, 44.5, 50.2, 51.9, 55.0, 58.3, 66.9, 67.1, 113.7, 127.6, 127.9, 128.3, 130.0, 130.2, 136.4, 156.3, 157.9; IR (film) 3406, 2935, 1684, 1512, 1454, 1334, $1248 \mathrm{~cm}^{-1}$; HRMS (FAB) calcd for $\mathrm{C}_{28} \mathrm{H}_{37} \mathrm{~N}_{2} \mathrm{O}_{5} 481.2697\left[(\mathrm{M}+\mathrm{H})^{+}\right]$, found 481.2694.

To a stirred solution of the above diol $(125 \mathrm{mg}, 0.260 \mathrm{mmol})$ in $\mathrm{CH}_{2} \mathrm{Cl}_{2}(20 \mathrm{ml})$ at $0{ }^{\circ} \mathrm{C}$ was added 1 - $H$-tetrazole $(182 \mathrm{mg}, 2.60 \mathrm{mmol})$. After stirring for $20 \mathrm{~min}$ at $0{ }^{\circ} \mathrm{C}$, Dibenzyl $(N, N$ diisopropyl)phosphoramidite $(90 \%)$ was added portionwise (slowly) until no starting material was detectable by TLC analysis (ca.147 $\square 1,0.49 \mathrm{mmol}$ ). When the reaction was completed, the reaction mixture was cooled to $-78{ }^{\circ} \mathrm{C}$. To the solution was added TBHP (5 M in decane) $(0.15 \mathrm{ml})$ and allowed to stir for $30 \mathrm{~min}$ at $-78{ }^{\circ} \mathrm{C}$ before the addition of saturated aqueous $\mathrm{Na}_{2} \mathrm{SO}_{3}$. The mixture was extracted with $\mathrm{CH}_{2} \mathrm{CH}_{2}$ and the combined organic layer was dried over $\mathrm{Na}_{2} \mathrm{SO}_{4}$. The solvent was removed under reduced pressure then resulting residue was purified by silica gel chromatography (AcOEt:hexane=4:1-MeOH: $\mathrm{CH}_{2} \mathrm{Cl}_{2}=2: 8$ ) to afford pure dibenzyl phosphate 17 (130 mg, $0.175 \mathrm{mmol}, 68 \%)$ as pale yellow oil.: ${ }^{1} \mathrm{H}-\mathrm{NMR}\left(\mathrm{CD}_{3} \mathrm{OD} \square 3.31,400 \mathrm{MHz}\right)$ 1.25-1.55 (2H, m), $1.69(2 \mathrm{H}, \mathrm{br}), 1.75-2.18(4 \mathrm{H}, \mathrm{m}), 2.26(1 \mathrm{H}, \mathrm{br}), 2.72(3 \mathrm{H}, \mathrm{s}), 2.75-2.97(3 \mathrm{H}$, m), $3.28(1 \mathrm{H}$, br), $3.40(1 \mathrm{H}, \mathrm{br}), 3.66(1 \mathrm{H}, \mathrm{br}), 3.76(3 \mathrm{H}, \mathrm{s}), 4.32(1 \mathrm{H}, \mathrm{br}), 4.71(1 \mathrm{H}, \mathrm{br}), 4.96-5.05$ $(4 \mathrm{H}, \mathrm{m}), 5.08(2 \mathrm{H}, \mathrm{s}), 6.84(2 \mathrm{H}, \mathrm{d}, J=9.2 \mathrm{~Hz}), 7.21(2 \mathrm{H}, \mathrm{d}, J=8.2 \mathrm{~Hz}), 7.34(10 \mathrm{H}, \mathrm{s}), 7.34(5 \mathrm{H}, \mathrm{s})$; ${ }^{13} \mathrm{C}-\mathrm{NMR}\left(\mathrm{CD}_{3} \mathrm{OD} \square 49.0,100 \mathrm{MHz}\right) 23.0,29.2,29.9,31.1,36.2,44.0,44.7,51.8,53.4,55.7,59.5$, 67.8, 68.3, 70.8, 77.0, 114.8, 128.8, 129.1, 129.2 129.5, 129.7, 129.7, 131.2, 132.2, 137.2, 138.1, 157.9, 159.6; IR (film) 3408, 2935, 1695, 1512, 1454, 1248, $1009 \mathrm{~cm}^{-1}$; HRMS (FAB) calcd for $\mathrm{C}_{42} \mathrm{H}_{50} \mathrm{~N}_{2} \mathrm{O}_{8} \mathrm{P} 741.3299\left[(\mathrm{M}+\mathrm{H})^{+}\right]$, found 741.3298 .

FR901483 (1)
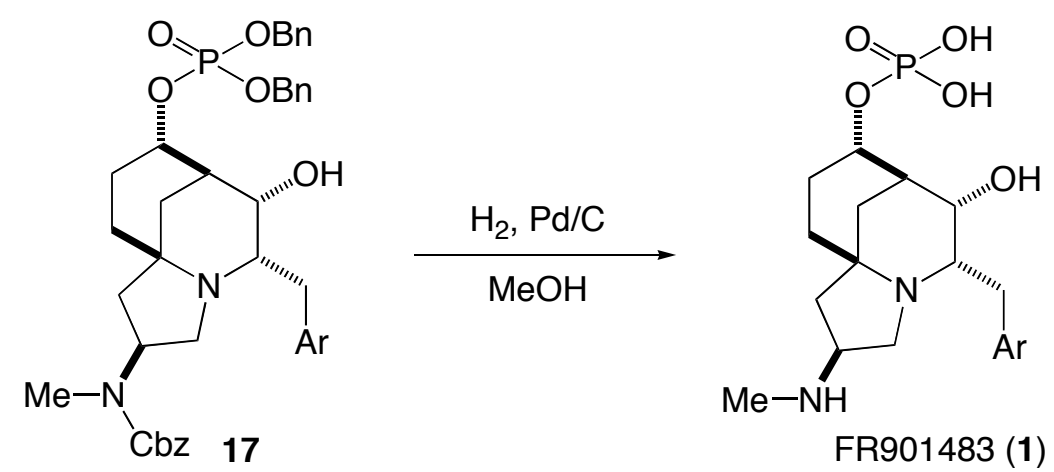

To a solution of dibenzyl phosphate 17 (54.2 $\mathrm{mg}, 73.1 \square \mathrm{mol})$ in $\mathrm{MeOH}(5 \mathrm{ml})$ was added 
aqueous $1 \mathrm{~N} \mathrm{HCl}(0.1 \mathrm{ml})$. The solvent was removed under reduced pressure giving $\mathrm{HCl}$ salt. $\mathrm{Pd} / \mathrm{C}$ $(10 \%$, dry $)(150 \mathrm{mg}, 141 \square \mathrm{mol})$ and $\mathrm{MeOH}(15 \mathrm{ml})$ were added, and the mixture was stirred at room temperature under 1 atom of hydrogen gas atmosphere for 5 hours and filtered over a pad of Celite, which was washed with $\mathrm{MeOH}$. The combined filtrate was concentrated under reduced pressure and then rinsed with $\mathrm{CH}_{3} \mathrm{CN}$ to give FR901483 (1) (19.7 mg, 46.2 ○mol, 63\%) as white solid.: ${ }^{1} \mathrm{H}-\mathrm{NMR}$ $\left(\mathrm{CD}_{3} \mathrm{OD} \square 3.31,400 \mathrm{MHz}\right) \square 1.91(1 \mathrm{H}, \mathrm{d}, J=13.7 \mathrm{~Hz}), 2.02-2.40(6 \mathrm{H}, \mathrm{m}), 2.45(1 \mathrm{H}, \mathrm{br}), 2.66(1 \mathrm{H}$, $\mathrm{dd}, J=9.2,13.7 \mathrm{~Hz}), 2.78(3 \mathrm{H}, \mathrm{s}), 3.11(1 \mathrm{H}, \mathrm{dd}, J=3.2,12.4 \mathrm{~Hz}), 3.64(1 \mathrm{H}, \mathrm{br}), 3.78(3 \mathrm{H}, \mathrm{s}), 3.85-$ $3.97(2 \mathrm{H}, \mathrm{m}), 4.22-4.35(2 \mathrm{H}, \mathrm{m}), 4.49(1 \mathrm{H}, \mathrm{dd}, J=9.6,13.3 \mathrm{~Hz}), 6.90(2 \mathrm{H}, \mathrm{d}, J=8.2 \mathrm{~Hz}), 7.33(2 \mathrm{H}$, $\mathrm{d}, J=9.2 \mathrm{~Hz}) ;{ }^{13} \mathrm{C}-\mathrm{NMR}\left(\mathrm{CD}_{3} \mathrm{OD} \square 49.0,100 \mathrm{MHz}\right) 22.4,27.7,28.2,32.4,34.0,41.7,42.8,51.9$, 55.0, 55.7, 62.0, 63.9, 68.8, 71.0, 115.3, 128.6, 131.7, 160.5; IR (film) 3336, 2933, 1612, 1514, 1458, 1248, 1180, $1009 \mathrm{~cm}^{-1}$; HRMS (FAB) calcd for $\mathrm{C}_{20} \mathrm{H}_{32} \mathrm{~N}_{2} \mathrm{O}_{6} \mathrm{P} 427.1992\left[(\mathrm{M}+\mathrm{H})^{+}\right]$, found 427.1996. 